\title{
Potential of few fungicides and plant extracts for managing charcoal rot of soybean caused by Macrophomina phaseolina (Tassi) Gold. in Madhya Pradesh, India
}

\section{Sanjay}

Department of Plant Pathology, College of Agriculture, Jawaharlal Nehru Krishi Vishwavidyalaya, Jabalpur-48200 (Madhya Pradesh), India

Sanjeev Kumar *

Department of Plant Pathology, College of Agriculture, Jawaharlal Nehru Krishi Vishwavidyalaya, Jabalpur-48200 (Madhya Pradesh), India

\section{Balkishan Chaudhary}

Department of Plant Pathology, College of Agriculture, Jawaharlal Nehru Krishi Vishwavidyalaya, Jabalpur-48200 (Madhya Pradesh), India

*Corresponding author. E mail: sanjeevcoa@gmail.com

\section{Article Info}

https://doi.org/10.31018/

jans.v12i3.2335

Received: July 26, 2020

Revised: August 21, 2020

Accepted: August 24, 2020

\section{How to Cite}

Sanjay et al. (2020). Potential of few fungicides and plant extracts for managing charcoal rot of soybean caused by Macrophomina phaseolina (Tassi) Gold. in Madhya Pradesh, India. Journal of Applied and Natural Science, $12(3)$ : 388 - 393. https://doi.org/10.31018/jans.v12i3.2335

\begin{abstract}
Charcoal rot disease of soybean caused by Macrophomina phaseolina is a serious problem in most of the soybean growing area of Madhya Pradesh. In this study, seven plant extracts viz., leaves of Azadirachta indica, Citrus limon, Polyalthia longifolia, Parthenium hysterophorus and Ricinus communis, bulb of Allium sativum and Allium cepa and eight fungicides viz., Captan (0.25\%), Mancozeb (0.25\%), Carbendazim + Mancozeb (25\%), Thiophanate Methyl (0.1\%), Pyraclostrobin (0.2\%), Carbendazim $(0.1 \%)$ and Blue copper $(0.3 \%)$ were evaluated for an effective management of charcoal rot of soybean caused by M. phaseolina (Tassi) Goid under in vitro and in vivo condition. Among plant extracts, garlic clove extract was found most effective showing $77.3 \%$ growth inhibition and poor microslerotia formation of $M$. phaseolina by $77.3 \%$ followed by parthenium leaf extract $(75.2 \%$ inhibition) at $15 \%$ concentration. Two soil drenching of garlic clove extracts @ $15.0 \%$ concentration also found most effective for the management of disease under field condition recorded minimum disease incidence (13.5\%) and highest yield (14.6q/ha). Among fungicides, Carbendazim (0.1\%) and Thiophanate Methyl $(0.1 \%)$ showed $100 \%$ inhibition of radial growth and microsclerotia production of $M$ phaseolina under in vitro condition. Two soil drenching of Carbendazim @ $0.1 \%$ found to be most effective for the management of charcoal rot of soybean under field condition showing minimum disease incidence $(5.36 \%)$ and producing highest yield (16.0 q/ha) followed by Thiophanate Methyl. These results suggested that the toxic effect of Carbendazim and Thiophanate Methyl and $A$. sativum inhibited maximum mycelium growth in vitro and provide management of charcoal rot disease under field conditions.
\end{abstract}

Keywords: Charcoal rot, Fungicide, M. phaseolina, Plant extract, Soybean

\section{INTRODUCTION}

Soybean [Glycine max (L.) Merr.] plants are susceptible to root and stem base rots caused by soil pathogens at all growth stages. One of these diseases is charcoal rot of soybean, caused by the polyphagous fungus Macrophomina phaseolina. This pathogen infects a wide host range of nearly 500 species in more than 100 families around the world (Reznikov et al. 2016). The disease is also a serious problem in most of the soybean growing area of Madhya Pradesh,
India (Amrate et al., 2020). The infection is seen in seedlings and proves to be fatal in most cases. The disease incidence was noticed in all the locations surveyed with a range from 16.91 to $26.76 \%$. Although considerable research related to the biology, ecology and management of pathogen has been conducted, it continuous to cause economic losses in soybean. No single management is effective under farmer's field (Reznikov et al., 2016).. Keeping in view, the abovementioned facts an investigation was undertaken to 
assess the efficiency of fungicides, and plant extracts for management of charcoal rot of soybean.

\section{MATERIALS AND METHODS}

Isolation and identification of pathogen: The causal organism was isolated from infected portion of the plants collected from Soybean experimental field, Department of Plant Breeding and Genetics, Jawaharlal Nehru Krishi Vishwa Vidyalaya- Jabalpur and was purified by single culture method, and pathogenicity of the pathogen was confirmed. The pathogen was identified by comparing characters with the description of the standard reference (Bernett, 1980) and its identity was confirmed as $M$. phaseolina and maintained form time to time by transfer to potato dextrose agar slants.

Evaluation of plant extract: In order to find out the efficacy of different plant extract against $M$. phaseolina, seven plant extracts viz., leaves of Azadirachta indica, Citrus limon, Polyalthia longifolia, Parthenium hysterophorus and Ricinus communis, bulb of Allium sativum and Allium cepa were used. Fresh leaves/ bulbs were collected and washed carefully in clean water. $100 \mathrm{~g}$ of each washed plant material was ground in Pestle and Mortar by adding equal amount $(100 \mathrm{ml})$ of sterilized water $(1: 1 \mathrm{~V} / \mathrm{W})$ and heated at $80^{\circ} \mathrm{C}$ for 10 minutes in hot water both. The materials were filtered through double-layered muslin cloth followed by filtering through sterilized What man No. 1 filter paper and the filtrate so obtained formed the standard plant extract solution (100\%). The stock solutions 5,10 and $15 \%$ concentration were made by adding 95, 90 and $85 \mathrm{ml}$ of sterilized potato dextrose agar media to obtain 5,10 and $15 \%$ concentration of plant extract. The inhibitory effect of plant extract on radial growth of $M$. phaseolina was studied at 5, 10 and $15 \%$ concentrations were used by applying poison food techniques under in vitro condition. Eight treatments having three replications were maintained. Five $\mathrm{mm}$ discs of 7 days old culture of $M$. phaseolina were cut with a sterilized cork borer and placed in the centre of plant extract amended petri plates. The control petriplates having PDA alone were inoculated in the same manner. These petriplates were incubated at $25 \pm 2^{\circ} \mathrm{C}$. The observations were recorded on radial growth at 96 hrs of incubation.

The seven plants extracts were furtherer evaluated at $15 \%$ concentration as soil drenching on charcoal rot of soybean under field condition. The experiment was conducted in soybean breeding Farm JNKVV Jabalpur (M.P.) during 2016-17 in Randomized Block Design with three replications using variety JS 335 with a row spacing of $45 \times 15 \mathrm{~cm}$ and plot size of $4 \times 1.5 \mathrm{~m}^{2}$. Standard plant extracts were prepared in cold water as per the method described above. The extract thus obtained was diluted to $15 \%$ by water and drenched around the root zone in the soil after disease initiation. Plot drenched with water only served as check. Two consecutive drenched at an interval of 15 days were given. Observations on disease incidence and \% disease control were recorded 120 days after sowing. The yields were recorded after harvest of the crop. Data were analyzed statistically.

Evaluation of fungicides: Eight fungicides viz., Cap$\tan (0.25 \%)$, Mancozeb $(0.25 \%)$, Carbendazim + Mancozeb (25\%), Thiophanate Methyl $(0.1 \%)$, Pyraclostrobin $(0.2 \%)$, Carbendazim $(0.1 \%)$ and Blue copper $(0.3 \%)$ and control having PDA alone were evaluated against $M$. phaseolina by "Poison Food Techniques" as described by Morton and Straube (1955). The required quantity of each fungicide was thoroughly mixed with $100 \mathrm{ml}$ of sterilized PDA medium contained in $200 \mathrm{ml}$ flakes. It was then mixed thoroughly and was poured in petriplates and allowed to solidity. Each treatment replicated thrice. The control petriplates having PDA alone were inoculated in the same manner. Five $\mathrm{mm}$ diameter of pathogen colony from seven days old culture of $M$. phaseolina was cut with the help of cork borer and inoculated at the center in each Petridish. The inoculated Petri-dishes were incubated at $25 \pm 2^{\circ} \mathrm{C}$. Observations were recorded on radial growth at 96 hrs of incubation.

Fungicides were further evaluated as soil drenching under field condition on charcoal rot of soybean under field conditions. The experiment was conducted in soybean breeding Farm JNKVV Jabalpur (M.P.) during 2016-17 in Randomized Block Design (RBD) with three replications using variety JS 335 with row spacing of $45 \times 15 \mathrm{~cm}$ and plot size of $4 \times 1.5 \mathrm{~m}^{2}$. The date of sowing was 23 June 2016 . Standard fungicides solutions were prepared and drenched around the root zone of the crop after disease initiation. Plot drenched with water only served as check. Two consecutive drenched at an interval of 15 days were given. Observations on disease incidence and \% disease control were observed 120 days after sowing. The yields were recorded after harvest of the crop. Data were analyzed statistically using R-Statistics program.

\section{RESULTS AND DISCUSSION}

Effect of plant extracts: Out of the seven plants extracts viz., A. indica, C. limon, $P$. longifolia, $P$. hysterophorus and $R$. communis, $A$. sativum and $A$. cepa evaluated, $A$. sativum clove extract was most effective as they inhibited the growth and poor sclerotia formation of $M$. phaseolina by $77.3 \%$ followed by $P$. hysterophorus leaf extract $(75.2 \%)$ at $15 \%$ concentration (Table-1). They were also found effective at $10 \%$ concentration also as they produced growth inhibition ranging respectively, between 63.6 to $71.3 \%$. A. indica leaf, $P$. longifolia leaf and $R$. communis leaf were also 
Sanjay et al. / J. Appl. \& Nat. Sci. 12(3): 388 - 393 (2020)

Table 1. Effect of plant extracts on radial growth and microsclerotia formation of $M$. phaseolina.

\begin{tabular}{|c|c|c|c|c|c|c|c|c|c|c|}
\hline \multirow[t]{2}{*}{ S.No. } & \multirow[t]{2}{*}{$\begin{array}{l}\text { Name of plant } \\
\text { extracts }\end{array}$} & \multirow[t]{2}{*}{ Local name } & \multirow[t]{2}{*}{$\begin{array}{l}\text { Parts } \\
\text { used }\end{array}$} & \multicolumn{3}{|c|}{$\begin{array}{l}\text { Radial growth (mm) } \\
\text { of target pathogen } \\
\text { (4 DAl)* }\end{array}$} & \multicolumn{4}{|c|}{$\begin{array}{cc}\begin{array}{c}\text { Percent growth inhi- } \\
\text { bition }\end{array} & \text { so. of micro- } \\
& \text { formed after } \\
& 21 \text { days }\end{array}$} \\
\hline & & & & $5 \%$ & $10 \%$ & $15 \%$ & $5 \%$ & $10 \%$ & $15 \%$ & \\
\hline 1 & Allium sativum & Garlic & Clove & 40.7 & 25.8 & 20.4 & 54.7 & 71.3 & 77.3 & Poor \\
\hline 2 & Parthenium hysterophorus & Parthenium & Leaf & 54.2 & 32.7 & 22.3 & 39.7 & 63.6 & 75.2 & Poor \\
\hline 3 & Polyalthia longifolia & Ashok & Leaf & 87.7 & 79.1 & 34.8 & 2.5 & 12.1 & 61.3 & Fair \\
\hline 4 & Citrus limon & Citrus & Leaf & 61.4 & 52.5 & 48.5 & 31.8 & 41.6 & 46.1 & Fair \\
\hline 5 & Azadirachta indica & Neem & Leaf & 53.3 & 40.7 & 31.1 & 40.7 & 54.7 & 65.4 & Poor \\
\hline 6 & Ricinus communis & Castor & Leaf & 55.3 & 51.7 & 37.7 & 38.5 & 42.5 & 58.1 & Fair \\
\hline 7 & Allium cepa & Onion & Bulb & 76.7 & 60.6 & 52.8 & 14.7 & 32.6 & 41.3 & Fair \\
\hline \multirow[t]{3}{*}{8} & Control (only PDA) & - & - & 90.0 & 90.0 & 90.0 & 00.0 & 00.0 & 00.0 & Excellent \\
\hline & $\mathrm{SE}(\mathrm{m})$ & & & 0.48 & 0.56 & 0.54 & & & & \\
\hline & CD (0.05) & & & 1.20 & 1.30 & 1.27 & & & & \\
\hline
\end{tabular}

Average of 3 replications

Table 2. Effect of plant extracts on disease incidence and yield of soybean.

\begin{tabular}{|c|c|c|c|c|c|c|}
\hline \multicolumn{2}{|c|}{ S.No. Plant extracts } & \multirow{2}{*}{$\begin{array}{l}\begin{array}{l}\text { Doses } \\
(\%)\end{array} \\
15 \\
\end{array}$} & \multirow{2}{*}{$\begin{array}{l}\begin{array}{l}\text { Disease } \\
\text { incidence } \\
(\%)\end{array} \\
13.5\end{array}$} & \multirow{2}{*}{$\begin{array}{l}\begin{array}{l}\text { Percent disease } \\
\text { control over } \\
\text { check (\%) }\end{array} \\
65.2\end{array}$} & \multirow{2}{*}{$\begin{array}{l}\begin{array}{l}\text { Yield } \\
\text { (q/ha) }\end{array} \\
14.6 \\
\end{array}$} & \multirow{2}{*}{$\begin{array}{l}\% \text { increase in } \\
\text { yield over check }\end{array}$} \\
\hline 1 & Allium sativum & & & & & \\
\hline 2 & Azadirachta indica & 15 & 16.4 & 57.2 & 12.6 & 35.0 \\
\hline 3 & Polyalthia longifolia & 15 & 21.6 & 43.6 & 10.9 & 17.1 \\
\hline 4 & Parthenium hysterophorus & 15 & 17.4 & 55.6 & 11.9 & 27.5 \\
\hline 5 & Ricinus communis & 15 & 33.7 & 12.0 & 10.3 & 10.3 \\
\hline 6 & Citrus limon & 15 & 35.0 & 8.6 & 9.6 & 3.5 \\
\hline 7 & Allium cepa & 15 & 23.5 & 38.6 & 11.0 & 17.8 \\
\hline \multirow[t]{3}{*}{8} & Control (only water) & -- & 38.3 & -- & 9.3 & -- \\
\hline & SE (m) & & 0.79 & & 0.52 & \\
\hline & CD (0.05) & & 1.90 & & 1.26 & \\
\hline
\end{tabular}

Average of 3 replications

found very promising as they produced only $65.4,61.3$ and $58.1 \%$ inhibition, respectively, at $15 \%$ concentration. At lower concentrations, i.e. 5 and $10 \%$ growth inhibition was due to $A$. indica leaf, $P$. longifolia leaf and $R$. communis leaf extract, $A$. cepa bulb and $C$. limon leaf extract were less than $55 \%$. No plant extracts were found effective at $5 \%$ concentration. The poor microsclerotia formation was observed in Allium sativum and Parthenium hysterophorus while fair to abundant microsclerotia formation was observed in other treatment. The result of the present study are in accordance with the findings of Savaliya et al., (2015), Hussain et al., (2014) and Chaudhary et al. (2019). Hussain et al. (2014) reported that $A$. sativum inhibited maximum mycelium growth followed by $P$. hysterophorus at all concentrations against M.phaseolina in vitro. The inhibition of fungal growth may be due to the presence of antifungal compounds such as glycoside, steroids, saponins, medicagenic acid, tannins, terpenoids and phobol esters (Anusha, 2003).

All the plant extracts at $15 \%$ concentration tested under field condition significantly $(p=0.05)$ reduced the disease incidence when compared with the check (Table 2). Two soil drenching of Allium sativum extracts @ $15 \%$ showed minimum disease incidence (13.5\%) and maximum yield (14.6 q/ha) followed by Azadirachta indica extract (164\%; 12.6 q/ha ) as compared to $38.3 \%$ disease incidence and $9.3 \mathrm{q} / \mathrm{ha}$ yield 
Sanjay et al. / J. Appl. \& Nat. Sci. 12(3): 388 - 393 (2020)

Table 3. Effect of fungicides on radial growth and microsclerotia formation of $M$. phaseolina.

\begin{tabular}{|c|c|c|c|c|c|c|c|}
\hline S. No & Fungicides & $\begin{array}{c}\text { Doses } \\
\text { (gm/ } \\
\text { liter) }\end{array}$ & $\begin{array}{c}\text { Radial } \\
\text { growth } \\
(\mathrm{mm}) \text { after } \\
72 \mathrm{hrs}^{*}\end{array}$ & $\begin{array}{c}\text { Growth } \\
\text { inhibition } \\
\text { over } \\
\text { control (\%) }\end{array}$ & $\begin{array}{l}\text { Radial growth } \\
\text { (mm) after } \\
96 \mathrm{hrs}\end{array}$ & $\begin{array}{c}\text { Growth } \\
\text { inhibition } \\
\text { over control } \\
(\%)\end{array}$ & $\begin{array}{c}\text { No. of } \\
\text { microsclerotia } \\
\text { formed after } \\
21 \text { days }\end{array}$ \\
\hline 1 & Pyraclostrobin & 0.2 & 30.9 & 63.6 & 39.6 & 55.9 & Fair \\
\hline 2 & Mancozeb & 2.5 & 44.4 & 47.7 & 65.5 & 27.2 & Fair \\
\hline 3 & Captan & 2.5 & 10.0 & 88.2 & 26.0 & 71.1 & Poor \\
\hline 4 & Copper oxychloride & 3.0 & 76.4 & 10.0 & 85.6 & 4.8 & Excellent \\
\hline 5 & Carbendazim & 1.0 & 0.0 & 100.0 & 0.0 & 100.0 & Nil \\
\hline 6 & $\begin{array}{l}\text { Thiophanate } \\
\text { Methyl }\end{array}$ & 1.0 & 0.0 & 100.0 & 0.0 & 100.0 & Nil \\
\hline 7 & $\begin{array}{l}\text { Carbendazim + } \\
\text { Mancozeb }\end{array}$ & 2.5 & 77.7 & 8.4 & 88.0 & 2.2 & Excellent \\
\hline \multirow[t]{3}{*}{8} & Control (Only PDA) & -- & 85.0 & - & 90.0 & - & Excellent \\
\hline & SE $(m)$ & & 0.48 & & 0.40 & & \\
\hline & $C D(0.05)$ & & 1.20 & & 1.29 & & \\
\hline
\end{tabular}

Average of 3 replications

Table 4. Effect of soil drenching of fungicides on disease incidence and yield of soybean.

\begin{tabular}{|c|c|c|c|c|c|c|}
\hline S. No & Fungicides & $\begin{array}{l}\text { Doses } \\
\text { (gm/ lit) }\end{array}$ & $\begin{array}{l}\text { Disease } \\
\text { incidence }\end{array}$ & $\begin{array}{l}\text { Percent inhibi- } \\
\text { tion over control }\end{array}$ & $\begin{array}{l}\text { Yield } \\
\text { (q/ha) }\end{array}$ & $\begin{array}{l}\% \text { increase in } \\
\text { yield over check }\end{array}$ \\
\hline 1 & Pyraclostrobin & 0.2 & 15.6 & 63.6 & 13.0 & 59.9 \\
\hline 2 & Mancozeb & 2.5 & 17.8 & 58.4 & 11.2 & 38.3 \\
\hline 3 & Captan & 2.5 & 10.0 & 76.6 & 14.0 & 72.2 \\
\hline 4 & $\begin{array}{l}\text { Copper } \\
\text { oxychloride }\end{array}$ & 3.0 & 29.0 & 31.7 & 9.9 & 22.0 \\
\hline 5 & Carbendazim & 1.0 & 5.3 & 87.5 & 16.0 & 96.8 \\
\hline 6 & $\begin{array}{l}\text { Thiophanate } \\
\text { methyl }\end{array}$ & 1.0 & 6.3 & 85.2 & 15.0 & 85.1 \\
\hline 7 & $\begin{array}{l}\text { Carbendazim + } \\
\text { Mancozeb }\end{array}$ & 2.5 & 23.4 & 45.4 & 10.8 & 32.8 \\
\hline \multirow[t]{3}{*}{8} & $\begin{array}{l}\text { Control (Plain } \\
\text { water) }\end{array}$ & -- & 42.96 & -- & 8.1 & -- \\
\hline & $\mathrm{SE}(\mathrm{m})$ & & 0.68 & & 0.10 & \\
\hline & CD (0.05) & & 1.31 & & 1.44 & - \\
\hline
\end{tabular}

Average of 3 replications

in control (Table 2). Datar (1999) reported that clove extract of $A$. sativum and bulb of $A$. cepa was found most effective in inhibiting mycelial growth of M.Phaseolina. Kane et al., (2002) reported that crude extract of a clove of $A$. sativum effective in inhibiting the mycelial growth of the M.Phaseolina to the extent of a cent \%. Dubey and Dwivedi (1991) found fungi toxic properties of clove extracts of $A$. sativum against vegetative growth and sclerotial viability of $M$. phaseolina. Muzammil et al., (2014) reported that leaf extract of $A$ indica extract was effective to inhibit the growth of the fungus at $15 \%$ concentration. These results support the present result in which $A$. sativum clove extract and leaf extract of A.indica was found most effective in managing the disease under field conditions.

Effect of fungicides: In vitro evaluation of fungicides provides useful preliminary information regarding its efficacy against a pathogen within the shortest period of time and therefore serves as a guide for further field testing. In the present study among the fungicides viz., Captan, Mancozeb, Carbendazim + Mancozeb, Thi- 
ophanate Methyl, Pyraclostrobin, Carbendazim and Blue copper evaluated, Carbendazim and Thiophanate methyl were found best fungicide which completely inhibited the radial growth and sclerotia formation of M. phaseolina (Table 3). Captan, Pyraclostrobin and Mancozeb were second next in order of toxicity resulting, respectively $71.11,55.93$ and $27.22 \%$ inhibition of radial growth. Copper oxychloride, Carbendazim + Mancozeb were not found effective in inhibiting the growth and microsclerotia production of $M$. phaseolina. Similar findings have been observed by Konde et al. (2008), Ray \& Kumar (2008), Shovan et al. (2008), Mallesh and Narendrappa (2008), Ramesh (2009), Muzammil et al. (2014), and Kumar et al. (2019) against Macrophomina spp. Most of them reported that Carbendazim was effective in inhibiting mycelia growth of $M$. phaseolina . It was concluded from the Table-3 that Carbendazim and Thiophanate methyl significantly $(p=0.05)$ inhibited the mycelia growth of M.phaseolina.The mechanism of fungicide is binding the b-tubulin polymer of pathogens which are responsible for nuclear division and directly stop the micotubulin activity. Carbendazim directly stops tubulin activity which is important for the growth of pathogens.

All the fungicides tested reduced the disease incidence when compared with a check under field condition. Two soils drenching of Carbendazim @ $0.1 \%$ showed minimum disease incidence of $5.36 \%$ and highest yield (16.0 q/ha) followed by Thiophanate Methyl $(6.34 \%, 15.05 \mathrm{q} / \mathrm{ha})$ (Table 4). Soil drenched with Captan, Pyraclostrobin, Mancozeb and Carbendazim + Mancozeb were second next in order of toxicity resulting, respectively $10.03,15.62,17.87$ and $23.43 \%$ incidence. Copper oxychloride was least effective in controlling charcoal rot of soybean. The disease incidence recorded in the check plot was $42.96 \%$. The result of the present study are in accordance to the findings of Konde et al. (2008), Muzammil et al. (2014) and Andrabi et al. (2011) who reported that Carbendazim 50 \% WP was more effective @ $2 \mathrm{~g} / \mathrm{kg}$ seed treatment showing least disease intensity $(22.6 \%)$ of Rhizoctonia root rot of soybean as against $49.3 \%$ in control. Kumar et al. (2019) reported that seed treatment with Carbendazim was the most effective against Rhizoctonia root rot of soybean.

\section{Conclusion}

It was concluded that the charcoal rot disease of soybean is prevalent in all major soybean growing areas like Jabalpur, Rewa, Satna and Indore districts of Madhya Pradesh. Among the plant extracts viz., leaves of $A$. indica, $C$. limon, $P$. longifolia, $P$. hysterophorus and $R$. communis, bulb of $A$. sativum and $A$. cepa and eight fungicides viz., Captan Mancozeb, Carbendazim + Mancozeb, Thiophanate Methyl, Pyra- clostrobin, Carbendazim and Blue copper evaluated for managing charcoal rot disease of soybean , Allium sativum clove extract, Carbendazim and Thiophanate methyl significantly $(p=0.05) \quad$ inhibited mycelium growth in vitro. The study would be helpful in the management of charcoal rot disease under field conditions.

\section{REFERENCES}

1. Amrate, P., Pancheshwar, D. and Shrivastava, M. (2020). Evaluation of soybean germplasm against charcoal rot, aerial blight and yellow mosaic virus disease in Madhya Pradesh. PI. Dis. Res. 33. 185-190.

2. Andrabi, M., Vaid, A. and Razdan, K. V. (2011). Evaluation of different measures to control wilt causing pathogens in chickpea. Journal Plant Protection Research. 51 (1). doi: 10.2478/v10045-011-0010-3.

3. Anusha, B.,(2003). Botanical fungicides for rice sheath blight management.M.S.(Ag), Tamil Nadu Agricultural University, Coimbatore, India, P.176

4. Bernett, H. L. (1980). Compendium of Soil Fungi. Buress Pub. Co. Minneapolis, USA p.223.

5. Datar, V. V. (1999). Bioefficacy of plant extracts against Macrophomona phaseolina (Tassi) Goid, the incitant to charcoal- rot of sorghum. Journal of Mycology and Plant Pathology. 29: 251-253.

6. Dubey, R. C. and Dwivedi, R. S. (1991). Fungi toxic properties of some plant extract against vegetative growth and sclerotial viability $M$. phaseolina. Indian Phytopathology. 44: 411-413.

7. Hussain M., Gazanfar M.U., Hamid M.I., Zahid M.A., Hussain T., Raza M \& Haq, A.U. (2014). In vitro evaluation of fungicides and plant extracts for suppressing mycelium growth of Macrophomina phaseolina causes charcoal rot os sunflower.Int. J.Agric. Appl. Sci.(6) 2,136-140.

8. Kane, P. V., Kshirsagar, C. R., Jadhav, A. C. and Pawar, N. B. 2002. In vitro evaluation of some plant extracts against Rhizoctonia bataticola in chickpea. Journal of Maharastra Agriculture University. 27(1): 101-102.

9. Konde, S. A., Raut, B. T. and Gade, M. R. (2008). Chemical and biological management of root rot (Rhizoctonia bataticola) of soybean. Annals Plant Physiology. 22(2): 275-277.

10.Kumar, A., Zacharia, S., Maurya, A. K. and John, V. (2019). Effect of fungicides and neem oil on the Rhizoctonia root rot of soybean (Glycine max L.). International Journal of Current Microbiology and Applied Sciences. 8(1): 368-372.

11.Mallesh, S. B. and Narendrappa, T. (2009). Management of root rot of sage, Salvia officinal is caused by Fusarium solani and Rhizoctonia solani. Indian Journal of Plant Protection. 37(1/2): 119-122.

12.Morton, D. T. and Straube, N. H. (1955). Antagonistic and stimulatory effects of microorganisms Sclerotium rolfsii . Phytopatho. 45: 419-420.

13.Muzammil, H., Muhammad, U. G., Muhammad, I. H., Muhammad, A. Z., Touseef, H., Mubashar, R. and UI Haq, A. (2014). In vitro evaluation of fungicides and plant extracts for suppressing mycelium growth of Macrophomina phaseolina causes charcoal rot of sunflower. International Journal of Agricultural Science. 6(2): 136-140. 
14.Ramesh, K. R. (2009). Inhibition of Rhizoctonia solani the causal agent for collar rot of teak (Tectona grandis) seedlings by fungicides and bio-control agents in in-vitro conditions. Indian Forester. 126(3): 284-288.

15.Reznikov, S., Vellicce, G.R., González, V. et al. (2016). Evaluation of chemical and biological seed treatments to control charcoal rot of soybean. $J$ Gen Plant Pathol 82, 273-280. https://doi.org/10.1007/s10327-0160669-4

16.Ray, A. and Kumar, P. (2008). Evaluation of fungicides against Rhizoctonia solani Kuhn, the incident of aerial blight of soybean. Pantnagar Journal Research. 6(1): 42-47.

17.Savaliya, V. A., Bhaliya, C. M., Marviyaand, P. B. and Akbari, L. F. (2015). Evaluation of phytoextracts against Macrophomina phaseolina (Tassi) Goid causing root rot of sesame. International Journal of Pharma and Bio Sciences. 8(2): 116-119.

18.Shovan, L. R., Bhuivan, M. K. A., Pegum, Z. A. and Pervez, Z. (2008). In-vitro control of Colletrotrichum dimatium causing anthracnose of soyabean by fungicides, plant extracts and Trichoderma harzianum. International Journal of Sustainable Crop Production. 3(3): 10-17. 